\title{
Pride and Prejudice Beyond the Glass Ceiling: brazilian FEMALE EXECUTIVE'S PSYCHOLOGICAL TYPE
}

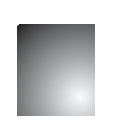

\author{
Orgulho e Preconceito além do Teto de Vidro: o tipo \\ psicológico das executivas brasileiras
}

\begin{abstract}
Antonio Carvalho Neto
Professor permanente do Programa de Pós-Graduação em Administração. PUC Minas. Belo Horizonte, MG. Brasil. E-mail: carvalhoneto@pucminas.br
\end{abstract}

\author{
Betania Tanure \\ Professor permanente do Programa de Pós-Graduação em Administração. PUC Minas. Belo Horizonte, MG. Brasil. E-mail: \\ betaniatanure@pucminas.br
}

\section{Carolina Mota-Santos}

Professora do curso de Psicologia da PUC Minas. Belo Horizonte, MG. Brasil. E-mail: cmotasotnas@yahoo.com.br

\begin{abstract}
This paper intends to relate characteristics of female executive psychological type with their male colleagues in corporations operating in Brazil (CEOs, VPs/directors and top managers). The theoretical framework explores the glass ceiling and the prejudices faced by female executives. It was developed a mixed qualitativequantitative method. In the quantitative part we interviewed 743 men and 222 women from 344 corporations. We applied also the questionnaire MBTI to 430 of these executives. In the qualitative part we held focus groups with 227 individuals and 104 semistructured interviews. The most active psychological MBTI type found was the ESTJ, both to men and women. The dominant characteristics in this type is more rational, logical and less emotional. Prejudices are huge: women need to work harder to show that they are as competent as men. They also live the society's pressure in relation to the roles as mother and wife.
\end{abstract}

Keywords: Female Executives Profile. Masculine Executives Profile. MBTI. Glass Ceiling. Prejudice.

\section{Resumo}

Este artigo relaciona características do tipo psicológico das mulheres executivas com as de seus colegas homens nas grandes empresas do Brasil (Presidentes, VicePresidentes/Diretores e terceiro escalão). O referencial teórico explora barreiras sofridas pelas executivas. O método de pesquisa foi quantitativo-qualitativo. Aplicou-se dois tipos de questionário: em 743 homens e 222 mulheres de 344 empresas; o MBTI (Myers-Briggs Type Indicator), indicador baseado em Jung, em 430 desses executivos. Na parte qualitativa realizou-se grupos de foco com 227 indivíduos e 104 entrevistas semiestruturadas. O tipo de MBTI mais frequente foi o ESTJ, para homens e mulheres, mais racional, lógico e menos emocional. Os preconceitos são enormes: elas precisam trabalhar muito para mostrar que são competentes como os homens e também sofrem pressão social sobre os papéis de mãe, esposa $e$ principal responsável pelo lar. Mesmo assim, elas são orgulhosas do sucesso conquistado e não querem voltar para casa.

Palavras-chave: Perfil das Executivas. Perfil dos Executivos. MBTI. Teto de Vidro. Preconceito. 


\section{INTRODUCTION}

Although there are women occupying executive positions on organizations in Brazil, the number is not representative yet, i.e., that is not consistent with the percentage of women working there (AGUIAR, 2007). It's common to hear the phrase: "We think that the woman's presence is important", but when we asked how many women there are in the corporation, Tanure, Carvalho Neto and Andrade (2007) have even heard the following: two women in a group of 1000 . In other words, $0,2 \%$ !

Despite the increase of the discourse of equality between men and women in areas such as education and culture, changes are rare when considering the hierarchical division of labor within firms. The issue of representation and participation of women in all levels of power is more discussed nowadays. However, why do women who had several achievements (education, civil equality) have such difficulty in reaching positions of command in business? (PERROT, 1998; MIRANDA, 2006)

To represent this difficulty, a term has been created: the glass ceiling. The glass ceiling is a symbolic representation of a transparent and subtle barrier, but strong enough to preclude the promotion of women to senior positions in the organizational hierarchy (STEIL, 1997). The term "glass ceiling" adopted in this study appeared in a special article in the Wall Street Journal about women in business in 1986. The article investigated the corporate world and the access of the female executives toward the top of their careers. Since its publication, the metaphor has become synonymous with an invisible barrier", quite effective, which aims to keep women away from more senior levels. (JACKSON, 2001; BOTELHO; MORAES; CUNHA, 2008; MIRANDA, 2006)

The patterns of exclusion and marginalization often persist in large part by the fact that men and women are still seen as opposites and complementary. Features associated with women are generally distant from what an enterprise searches and features related to men are distant from those expected from someone who should care for the family and home. (ROCHA-COUTINHO, 2003)

Unlike men, who were always expected to occupy the leading roles, in Brazil women were subordinated to roles that somehow prevented them to come to positions of greater status, power and decision. In addition to the need to fight more to be able to acquire the competences to senior positions, women still have to prove more than men (BOTELHO; MORAES; CUNHA, 2008). For this, there are handbooks in the literature that "teach" the female executive to participate of the game of business and take advantage of it, such as Evans (2000).

What can be seen through the literature is that the dispute in order to equalize opportunities for hierarchical positions makes women "wear their masks" to absorb typically male characteristics that prevail in the workspace (MIRANDA, 2006). To get there and keep the position, many female executives are choosing to use the characteristics seen in our society as male features.

Given this context, the main objective of this paper, which is the result of an extensive research on the (un) happiness of the executives of Brazilian corporations in relation to their life at work and outside it, was to identify the most relevant features of the female executive in Brazil and the possible correlations with the characteristics of male executives who work at the top of Brazilian companies chain of command.

\section{Female Executives in Brazil}

Despite the literature indicating the strengthening of the participation of Brazilian women in the labor market, thus causing deep cultural changes, such as some division of household responsibilities (MAGESTE; MELO; CKAGNAZAROFF, 2008), and causing an appreciation that is often used even as a competitive differential of enterprises in the achievement of new markets (BOAS; NETO; CRAMER, 2003), researches in different fields go against the grain of this analysis. In other words, despite the intense changes in recent decades, the world of work continues to be defined according to male patterns. (ROCHA-COUTINHO, 2003)

Most of the organizations in Brazil are dominated by values related to male sex and thus distort the organizational life in favor of man in relation to women. Generally they exhibit characteristics such as rational, analytical, strategic, tough and aggressive, as well as the male stereotypes. The exclusion of women from 
leadership positions may be a reflection of the values of male groups, which do not consider the organizational environment the proper place for the female group. Despite the period of changes announced by the organizational literature, the phenomenon of the glass ceiling remains impassable. (STEIL, 1997; RAGO, 2001; MORGAN, 1996; MIRANDA, 2006)

The main cause of disparities reduction between men and women was the migration of women into male occupations. However, it is undeniable that in the Brazilian organizations the vast majority of women have had no voice in the formulation and discussion of frameworks that guide and discuss the relevant issues of economics and management. Despite the advance of the executive woman, we are still far from a balance. The evolution of female employment is a situation of lights and shadows. (THIRY-CHERQUES; PIMENTA, 2003; ABRAMO, 2007)

In the large companies operating in Brazil it still occur a considerable load of sexist prejudice, and added to other factors, the barriers to high career demands are monstrous. The woman needs, for example, to work "as a man" versus being "feminine", must "be as good at work as a man". (TANURE; CARVALHO NETO; ANDRADE, 2006)

This situation attracts attention when we realize that some female executives do not even notice the prejudice, assuming it as a compliment. In other words, the sexist stereotypes are so culturally deep-rooted that some women executives do not even perceive them as such. Other studies corroborate this male model of management adopted by female executives. Female executives assume that they manage the companies with the masculine style, although most do not even realize their management style is so masculine. (BOSCARIN; GRZYBOVSKI; MIGOTT, 2001; TANURE; CARVALHO NETO; ANDRADE, 2006)

Relations between men and women are often determined by predetermined stereotypes, traits that are traditionally associated to the fact of being male or female in western society. Male stereotypes are linked to logic, reason, strategy, independence and competitiveness. Feminine stereotypes associated with intuition, emotion, submission, empathy and cooperation. However, these stereotypes are in a period of transition. (MORGAN, 1996)
If women are not considered suitable for professions traditionally performed by men, it is not because they do not have technical abilities, but because they do not have the symbols, do not correspond to the figures of heroes and do not adopt dominant values of the male culture (HOFSTEDE, 1991). Belle (2001) adds that, although the model of woman imposed in the nineteenth century (woman who was in the company, but on a less qualified job, poorly paid and rarely at a level where they exercised power) is contested nowadays, we should not forget that if some gaps are opened, the company is primarily a men's world. It was neither designed nor made by women.

We cannot forget that women will always have to position themselves in a context where the outstanding values are more or less masculine. After all, what men think about executive women can still influence the destination of their careers. However, it is now recognized that people who will be able to integrate the two seemingly contradictory "masculine and feminine" trends of the exercise of power (paternal and authoritarian aspect/maternal aspect linked to behavior of persuasion and seduction) will have greater opportunities for success. (BELLE, 2001)

Although the masculine is the model still predominant in organizations (based on aggressiveness, authority, focus on the task) there seems to be an incentive, at least at the level of discourse, of a more participative management which would approach the feminine way to lead (Lima, 2009). Some organizations have more flexible structures that facilitate the connection of all employees. However, female stereotypes still today inspire little respect in the corporate arena. Differences in attitudes, when present, serve as one more reason for the sexist organizational culture move the woman away and prevent her from reaching the higher positions. (LEITE, 1994)

In a research aimed to identify and analyze the main challenges of the careers of top executive women, Lima (2009) points out that the executive woman is distinguished from other categories of women because they present different challenges and aspirations. They command men, compete with them and win the race. However, what is common is the fact that, like other women, the winning female executive is also less recognized than the male executive. 
Another observed factor was the discriminatory process which appears in the form of prejudice and lack of opportunities. Female executives need to invest more in work than men to overcome the obstacles that are also greater for women. Beyond technical competence, they need to internalize the attributes that men value because they are in a male environment. (LIMA, 2009; TANURE; CARVALHO NETO; ANDRADE, 2007)

Adopting "masculine" traits to be accepted in the organizational environment can be dangerous, because the "masculinization" of executive women's behavior makes the other side - the feminine features that are needed and not found in the masculine business world - still do not appear (TANURE; CARVALHO NETO; ANDRADE, 2007). Using the rules of men is to admit that the way of being female is not fitted to business, it constitutes a waiver. This position is not clear to the female executives yet. Lima (2009) in a research done with 40 executives, men and women, noted that the female executives do not have common demands. Some of them believe they should use the "male" attributes as a way to achieve career success. Others assume that there really is a "feminine" style of leadership and that they must fight for its place in the organization.

In the same vein, in another study also with Brazilian female executives, Bruschini and Puppin (2004) show that when talking about the personal characteristics of the executive women, these women present many contradictions in their statements. Some of them believe that the feminine style is different from the masculine style. The woman would have a sharper feeling and the man is more rational. Others say different, that in the corporate culture there is no room for feeling. Women who reach the power have a more logical profile. Some female executives even say that the woman must become a man to succeed because the company culture cannot be changed: either they adapt to it or end up leaving. Discrimination happens in an obfuscated way; for example, several barriers come by reason of pregnancy, four months of maternity leave and because of difficulties anticipated with small children and less availability to travel.

If men were educated and trained all their lives to exercise the speech, the discourse and the power, just about three decades ago women began to be trained, educated for these roles. Therefore, it is a short time to cause a structural change in society and culture.
However, despite this exclusion, many women today are aware that they need to be changement agents, opinion makers and able to confidently perform the activities to act in the public space. (PORTO, 2007)

Although there are certain stereotypes for men and women, since ancient times to modernity History is full of narratives starred by female warriors, despite History books are discreet or negligent when talking about them. Female warriors acted as soldiers performing tasks of domination, in contrast to the role assigned by society to the woman: to serve. Women warriors have always existed. People like the Arabs, Berbers, Kurds, Chinese, American Indians, at different times in History have had women soldiers.

These female warriors, often, not surprisingly, are called by men, generically, of amazons, a word that means "without breast". Besides the obvious symbolism of "masculinization", the explanation for this term is that they practiced the removal of the right breast to better extend the bow and shoot the arrow. But, despite they are not mentioned in the official military history, there is a book written about them, Amazons of Black Sparta, written by the historian Stanley B. Alpern. Alpern (1998) presents the history of women warriors and shows a list of cultures which had armies of women able to fight, in Australia, Polynesia, Asia, Africa and Europe. Some of these armies composed exclusively of women, in many occasions defeated the masculine armies.

As the organizational world is a new and different environment for women, one would expect a lack of consensus among them regarding which approach to choose. Faced with so many obstacles, it is noticed that the executive woman is adrift: does she have to act by using her identity, her most important features? Or does she have to use attributes that are most valued in the current environment where she works?

To leave home boundaries, women needed to use masculine stereotypes to be accepted. "Some of the early feminists cut their hair very short and wore baggy pants, trying to look like men" (FRIEDAN, 1971). But, if she starts to use the masculine attributes, it can be a dangerous path, with risk of always being seen as supportive. On the other hand, if she assumes the female identity, she can be seen as weak, not aggressive, generating, thus, distrust about her competence. (LIMA, 2009) 
Despite the difference in the salary, many executive women even believe that prejudices against women do not exist (in the case of selection and promotion), because in these cases the process would be based on criteria of competence and dedication to work. For these executive women, promotions occur more easily for those who are more likely to get around. Being available 24 hours a day for the company has as a result the fact of staying less with their children. "A position of middle manager enables them to better combine professional and personal roles than a strategic management level, which requires many trips" (BRUSCHINI; PUPPIN, 2004, p. 136; TANURE; CARVALHO NETO; ANDRADE, 2007). Despite this disadvantage, some female executives who reached the top believe that against competence there are no arguments.

From executive women who have "reached the top", those ones that are at the most strategic level, the belief that the competence is what matters, often prevents them from seeing the barriers, the discrimination and the prejudice in relation to the woman who works at Brazilian companies, as there are so few who arrive there. Only 23\% of top executives in Brazil are women. (TANURE; CARVALHO NETO; ANDRADE, 2007)

It is clear that gender relations are structured in front of a backdrop built to ensure a historical domination of masculine over feminine. However, it is noticed that the evolution of organizations depends on the recognition of the existing plurality in each subject, and this involves a greater acceptance and recognition of women's labor by men (CAPPELLE et al., 2004). The future will depend on the ability that men and women will have to negotiate their interests and, despite the differences, build a place of opportunities for all.

The next item is about the MBTI tool used to verify the most striking features of male and female executives.

\section{The MBti Tool to Measure the Characteristics of Male and Female EXECUTIVES}

The Myers-Briggs Type Indicator (MBTI) is a tool that was developed by Katharine Briggs and her daughter, Isabel Myers. Based on the work of Carl G. Jung, the MBTI performs an analysis on the personalities by the observation of the eight preferences (extroversion, introversion; sensing; intuition; thinking, feeling; judging, perceiving) used by people at different times. (MYERS, 1995)

The MBTI is a questionnaire that was prepared to understand Jung's theory of psychological types. In the beginning, applied primarily in individual therapy, the indicator is now widely used in team building, business management, education and vocational guidance. (MYERS; MYERS, 1997)

Figure 1 shows how Jung understood mental processes.

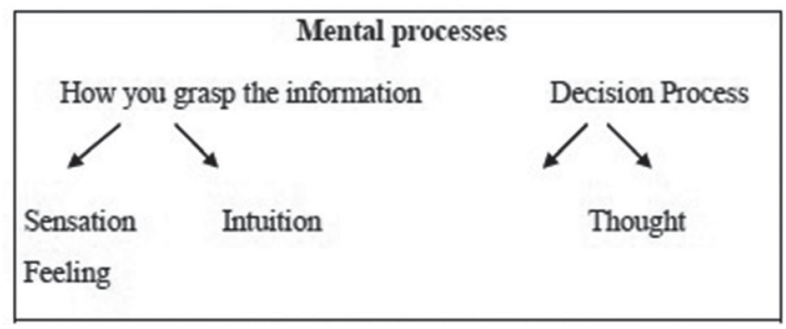

Figure 1: Mental processes

Source: Adapted Myers (1995)

Jung observed that there are two opposite ways through which things are perceived: Sensing and Intuition. Furthermore, there are two ways through which facts are judged and decisions are processed: Thinking and Feeling. (MYERS, 1995)

People use these four essential processes in the outer world and in the inner world. Jung called the outer world of people, things and experiences of Extroversion, and the inner world of processes and internal reflections of Introversion. The four basic processes used in the outside world as well as in the inner world provide eight different ways people can use their minds. (MYERS, 1995)

Jung realized that, depending on the preference regarding the focus of attention, that is, extroversion or introversion, the person has different skills which are reflected on their performance and on the way of seeing the world by expressing different behaviors. (OLIVEIRA; MURITIBA; CASADO, 2004)

The MBTI indicates the differences between people and these differences result from Extroversion or Introversion - where people prefer to focus their attention; Sensing or Intuition - the way people prefer to collect information; Thinking or Feeling the way people prefer to make decisions; Judging or Perceiving - how they are oriented on the outside 
world, whether they prefer to use especially the Judging process or the Perceiving process in relation to the outside world. (MYERS, 1995)

Motivation refers to the extent that the person prefers to focus their attention (EI scale). People who prefer Extroversion tend to focus on the external world of other people and events. They have a preference for taking energy from the outer world of people, activities or things. People who prefer Introversion tend to focus their attention on their own inner world of ideas and experiences. (MYERS, 1995)

In the extroverted attitude, attention seems to flow to the objectives and people of the environment. There is a desire to act on the environment, to affirm their importance. People who habitually take extroverted attitudes may develop some or all of the characteristics associated with extroversion: confidence in the environment and, sometimes, an impulsive way of dealing with life, frankness, easy communication and sociability. On the other hand, in the introverted attitude the energy is taken from the environment and consolidated internally. The main interest is in the inner world of concepts and ideas. These people may also have some or all of the characteristics associated with introversion: the interest in clarity of concepts and ideas, confidence in enduring concepts more than on external and transient events, and pleasure in solitude and privacy. (MYERS; MCCAULLEY, 1985)

The observation is about how information are obtained, how things are discovered (SN scale). People who prefer the Sensing dimension like to obtain information through the five senses and observe what is real. They observe what is happening around and easily recognize the practical reality of a situation. People who prefer Intuition like to obtain information by observing the whole, focusing on the connections and relations between facts. (MYERS, 1995)

People who prefer Sensing are by nature lovers of pleasures and love life as it is; they have a great capacity for pleasure and are in general happy. They prefer the art of living in the present, the satisfactions of achievement and acquisition. Wishing mainly to have the pleasure and being very observant, they are imitative, want to have what others have and do what others do, and are very dependent on their physical environment; however, they contribute to public wel- fare, that is, help any kind of pleasure, recreation, and all variety of comfort.

People who prefer Intuition are initiators by nature, inventors and promoters. They are generally impatient. They do not like occupations that require concentration of feelings and they are prepared to sacrifice the present since they do not really live in it and neither particularly appreciate it. They give little or no attention to the art of living the present. Being very imaginative, they are inventive and original, rather indifferent to what others have and do. They are independent of their physical environment, contribute to public welfare with their intelligence, initiative and with the powers of inspirational leadership. (MYERS, 1980)

Decisions, as its name implies, is how decisions are made (scale TF). People who prefer the Thinking to make decisions usually observe the logical consequences of a choice or action. They prefer to organize and structure information to make decisions in a logical and objective way. People who prefer the Feeling to make decisions take into consideration what is important to them and to others. They prefer to organize and structure the information to make decisions in a personal way and oriented to values. (MYERS, 1995)

People who prefer thinking value logic more than feeling. They are people more interested in things than in human relations. Naturally brief, they sometimes seem without friends and socially without interests for that. They are people who tend to question the conclusions of others believing that they are probably wrong. They are stronger in executive skills than in social arts. When the preference is for feeling, these people are naturally friendly and value feeling more than logic. They are more interested in people than in things. They tend to agree with those around them, and believe they are probably right. They are stronger in social arts than in executive skills. (MYERS, 1980)

Regarding the Mode of life, that is, how you find your way around in your relation with the outside world (JP scale), people who prefer to use the Judging process in the outside world tend to live in a planned and methodical way, trying to control life. People who prefer to use the process of Perceiving in the outside world tend to live in a very flexible and spontaneous way, trying to experience and understand life, rather than control it. (MYERS, 1995) 
In the perceptive attitude, the person is attuned to incoming information. These people seem to be spontaneous, curious and adaptable, open to new events and changes. In the judgmental attitude, people are linked to make decisions, planning operations or organizing activities. People who prefer the judgment process seem to be organized, purposeful and decisive. (MYERS; MCCAULLEY, 1985)

People who prefer judging are more decisive than curious. They live according to plans, standards and customs. They have pleasure in seeing something done, thus unhindered and free from thinking about it, that is, they like to have things decided as promptly as possible. In contrast, those who prefer the perception are more curious than decisive, moreover they are flexible, adaptable and tolerant. They live according to the present situation and adjust easily to the unexpected. They are happy to start something new. (MYERS, 1980)

The psychological type is determined by the four "chosen" preferences when answering to questions from the MBTI. As each of the eight preferences can be for a letter ( $\mathbf{E}$ - extraversion, $\mathbf{I}$ - Introversion, $\mathbf{S}$ - sensing, $\mathbf{N}$ - Intuition, $\mathbf{T}$ - thinking, $\mathbf{F}$ - feeling, $\mathbf{J}$ judging ou $\mathbf{P}$ - perceiving), a four-letter code is used to indicate the psychological type. The combination of the four scales of preference results in 16 psychological types (MYERS, 1995) as shown in Table 1.

Table 1: Effects of combinations

\begin{tabular}{|c|c|c|c|c|c|}
\hline & $\mathbf{S}$ & $\mathbf{S}$ & $\mathbf{N}$ & $\mathbf{N}$ & \\
\hline $\mathbf{I}$ & ISTJ & ISFJ & INFJ & INTJ & $\mathbf{J}$ \\
\hline $\mathbf{I}$ & ISTP & ISFP & INFP & INTP & $\mathbf{P}$ \\
\hline $\mathbf{E}$ & ESTP & ESFP & ENFP & ENTP & $\mathbf{P}$ \\
\hline $\mathbf{E}$ & ESTJ & ESFJ & ENFJ & ENTJ & $\mathbf{J}$ \\
\hline & $\mathbf{T}$ & $\mathbf{F}$ & $\mathbf{F}$ & $\mathbf{T}$ & \\
\hline
\end{tabular}

Source: Myers (1995)

\section{Methodological Considerations}

This research is part of a broader study on the (un) happiness of Brazilian executives and their sources of tension. The research method adopted in this study is the descriptive. A descriptive research is characterized by having well defined goals, formal procedures studied and directed towards problem solving or evaluation of alternative courses of action (MATTAR, 1999). Moreover, it is used when the objective is: 1) to describe the characteristics of groups; 2 ) to estimate the proportion of elements in a specific population that have certain characteristics or behaviors; 3 ) to discover or verify the relationship between variables. Therefore, it applies to this research.

As a research strategy was developed mixed qualitative-quantitative method, as explained by Creswell (2003), where one complements the other.

The sample universe was composed of executives from the 500 biggest companies located in Brazil. The research was conducted with male and female executives (presidents, vice-presidents/directors and third level top managers) of 344 private corporations operating in all economic sectors, in all demographic regions of Brazil, mainly located in the southeast.

In the quantitative part, we sent 1200 questionnaires to the 500 best evaluated as the biggest and the best performers in the Brazilian market. Of these, 965 questionnaires were received and considered valid, 743 from men and 222 from women who reached the top of the organizational hierarchy of these 344 companies. Quantitative data were collected through a closed questionnaire via Internet. Completing the set of quantitative data, we also applied the MBTI tool - Myers-Briggs Type Indicator - to 430 executives of this total sample of 965 . The applied sample of the MBTI questionnaire is statistically consistent as well as representative of the universe of 965 . This quantitative research aimed to compare MBTI of male and female executives. Male executives are the majority, reflecting the reality.

In the first field survey of the qualitative part were interviewed 263 male and female executives of 10 large enterprises among those 344 , who occupy the same hierarchical positions of the quantitative research described above, through semi-structured interviews, 96 of whom were interviewed individually and 167 by focus group (215 men and 48 women). Each focus group occurred just once. The authors of this article conducted these focus groups as well as the individual interviews during nine years. The interviews and focus group were asked about the differences and similarities between male and female executives related to pre- 
judices, barriers to women careers, balance between work and family.

Using the questionnaire of the first survey conducted since 2005, we held focus groups and individual semi-structured interviews with the same level of men and women managers in more 7 corporations. In this second field survey of the qualitative part were interviewed more 68 male and female executives, eight of whom were interviewed individually and 60 through focus groups (29 women and 39 men).

Given this, it was possible to generalize the results. Achieving a qualitative study of such scope and volume of data with this public and in a period of five years is rare even in the international literature.

From this research, were selected quantitative and qualitative data related to the characteristics of male and female executives, with the purpose of identifying the most relevant behavioral characteristics of Brazilian executive women and the possible relationships with the characteristics of executive men who work on top of Brazilian companies.

Considering the proposed methodology, the number of variables and sample size, we used the statistical tools described below, to proceed to the processing of data.

a) $H_{o}$ : The variables are independent.

b) $H_{1}$ : The variables are not independent, that is, they have some association.

The Chi-Square test evaluates the association (not necessarily linear) between two categorical variables, in which at least one of them is not ordinal. This comparison is made using a statistic that compares the values observed in each category with the expected values (estimated), and since "p" - value of this statistic - Is less than or equal to 0.05 , is said that there is a statistically significant association between the variables in question. The variance analysis, ANOVA (to one factor) is a technique used to test the equality of three or more means, at the same time, from independent samples. ANOVA to one factor means that the feature - factor - that differentiates each sample is the same. For example, in the comparison between positions, the factor that differentiates one sample from the other one is the position of individuals. The comparison between samples is made using a statistical test to evaluate pri- marily the variation between samples, and the greater this variability, the greater the evidence against the hypothesis of equality of means. Thus, when the "p" value of this statistic - Is lower than 0.05 , is stated that there is some difference between the means assessed. However, this test does not indicate just where that difference is. To this end, the method of multiple comparisons (Duncan method) was used, which shows the samples that presented significant difference compared to the others (compared in pairs).

In the tables of analysis of variance (comparison of various means), the values with same superscript letter (e.g., $4.83^{\mathrm{a}}$ and $4.56^{\mathrm{a}}$ ) are statistically similar, that is, there is not statistically significant difference between them. When the value has more than one letter (e.g., $3.18 \mathrm{a}, \mathrm{b}$ and $3.10 \mathrm{a}, \mathrm{b}, \mathrm{c})$, it has no significant difference between the groups corresponding to the letters $a, b$, $\mathrm{c}$, that is, the value is statistically similar to more than one category.

a) $H_{o}$ : The means are all equal.

b) $H_{1}$ : At least one mean is different.

The Factor Analysis is used when there are a large number of variables, as in this study, and we need to group them into a smaller number, in order to facilitate the study. In this analysis, the information contained in $\mathbf{p}$ variables is replaced by the information summarized by $\mathbf{k}$ variables, where $\mathbf{k}<\mathbf{p}$. These new $\mathbf{k}$ variables are called factors and may be used in other statistical analysis such as variance analysis or regression.

\section{Presentation and Analysis of Results}

Regarding the outcome of the MBTI, the data show a significant similarity with respect to the gender. Of the women who reach top managerial positions, $24.7 \%$ are ESTJ. It is noteworthy that there is no presence of the preference $(\mathrm{F})$ - feeling; that is, the dominant characteristic in the behavior of these women is not related to issues of greater interest in people than in things. These are women who value logic more than feelings (ESTJ type). Furthermore, they demonstrate that they are less intuitive because there is also no presence of the preference $(\mathrm{N})$, as shown in Table 2. 
Table 2: MBTI x gender

\begin{tabular}{|c|c|c|c|c|}
\hline MBTI & \multicolumn{1}{|c|}{ Feminine } & Masculine & \multicolumn{1}{c|}{ Total } & \% of TOTAL \\
\hline ESTJ & $24,7 \%$ & $22,4 \%$ & 93 & $22,9 \%$ \\
\hline ISTJ & $11,8 \%$ & $15, \%$ & 58 & $14,3 \%$ \\
\hline ESTP & $10,8 \%$ & $9,3 \%$ & 39 & $9,6 \%$ \\
\hline ENFP & $8,6 \%$ & $1,9 \%$ & 14 & $3,4 \%$ \\
\hline INTJ & $6,5 \%$ & $11,2 \%$ & 41 & $10,1 \%$ \\
\hline ENTP & $6,5 \%$ & $8,3 \%$ & 32 & $7,9 \%$ \\
\hline ESFJ & $6,5 \%$ & $2,2 \%$ & 13 & $3,2 \%$ \\
\hline ENFJ & $6,5 \%$ & $1,6 \%$ & 11 & $2,7 \%$ \\
\hline ISTP & $5,4 \%$ & $3,5 \%$ & 16 & $3,9 \%$ \\
\hline ENTJ & $4,3 \%$ & $17,9 \%$ & 60 & $14,8 \%$ \\
\hline INTP & $4,3 \%$ & $3,8 \%$ & 16 & $3,9 \%$ \\
\hline INFJ & $4,3 \%$ & $2,9 \%$ & 13 & $3,2 \%$ \\
\hline Total & $100, \%$ & $100, \%$ & 406 & 100, \\
\hline
\end{tabular}

Chi-Square: P-value $=0,001$

Source: Research data

The presence of the ESTJ can be explained by the fact that the organizational environment still have a culture which is predominantly masculine, that is, an environment that does not accept the expression of feelings clearly. Thus, this environment ends up selecting women who value logic more than feelings.

In relation to men, the data show that $22.4 \%$ are also ESTJ. Given this, the most active psychological type in organizations is the ESTJ, both in relation to men and women.

The data also indicate that the three types that are more common among women are ESTJ, ESTP and ISTJ. In relation to men the three most frequent types are: ESTJ, ENTJ and ISTJ. The difference lies in relation to the ENTJ, more present in men than in women, and ESTP, which, in contrast, is found more frequently in female executives than in male executives.

As we saw, the difference between the type ESTJ and ISTJ is that the former uses the preference E - extroversion. People of this type tend to focus on external world. The type ISTJ uses the preference IIntroversion. These are people who focus their attention on their own inner world of ideas and experiences.

Assessing the predominant pairs of letters, the data indicate that the $\mathrm{TJ}$ pair appears in the two groups of letters described above. It is noteworthy, as discussed by Myers (1995), that, in the preference T (Thinking), individuals prefer to decide organizing and structuring logically (objectivity), while in the preference F (Feeling), individuals prefer to decide taking into account what is personal (values). In the preference J (Judging), individuals prefer to live in a planned and organized way, while in the preference $\mathrm{P}$ (Perception), they prefer to live in a flexible and spontaneous way. Furthermore, we should emphasize that thinking people $(\mathrm{T})$ prefer jobs that require a logical order, especially with ideas, numbers or physical objects. The judges $(\mathrm{J})$ prefer jobs that impose the necessity of system and order, as emphasized in the discussed literature. (MYERS; MCCAULLEY, 1985)

Therefore, the results indicate that, in Brazilian organizations, people who are in top management positions prefer characteristics of behaviors more objective, rational and planned.

There are also significant differences, when analyzing gender and MBTI dismembered. The results show that among women there is a higher prevalence of type "T" $(74.2 \%)$ than the "F" $(25.8 \%)$, that is, women who are in management positions value more the logic. The same applies to men. There is a greater prevalence of type "T" (91.4\%) than the type "F" (8.6\%). These data confirm the presence of strong skills to work in executive areas of people with type "T" (Myers, 1980), as shown in Table 3.

The data also indicate that when considering only the "F" type, women $(25.8 \%$ of women compared to $8.6 \%$ of men) value more the type "F" - feeling. However, when analyzing the set, the preference for the type ' $\mathrm{T}$ ' is confirmed for both men and women.

Table 3: MBTI dismembered $\mathrm{x}$ gender

\begin{tabular}{|c|c|c|c|c|c|}
\hline \multicolumn{3}{|c|}{ GENDER } & \multicolumn{2}{|l|}{$\mathbf{F}$} & TOTAL \\
\hline & Feminine & Frequency & 24 & 69 & 93 \\
\hline & & $\%$ of Gender & $25,8 \%$ & $74,2 \%$ & $100,0 \%$ \\
\hline & Masculine & Frequency & 27 & 286 & 313 \\
\hline & & $\%$ of Gender & $8,6 \%$ & $91,4 \%$ & $100,0 \%$ \\
\hline \multirow{2}{*}{\multicolumn{2}{|c|}{ Total }} & Frequency & 51 & 355 & 406 \\
\hline & & $\%$ of Gender & $12,6 \%$ & $87,4 \%$ & $100,0 \%$ \\
\hline
\end{tabular}

Chi-Square: P-value $=0,000$

Source: Research data 
According to our qualitative research the evolution of female employment is a situation that still has more shadows than lights. Especially in the case of executive women who are at the top of organizations because they must demonstrate all the time that they are competent. The statement of one female executive interviewed exemplifies this:

"The insertion of a woman is more difficult, she has to go a step further than the man and show that she is more capable than him technically". (female executive 1)

Several were the examples used by the female executives to show that the organizational environment is somehow the "stronghold" of men and women must strive much more to get space in this environment. One female executive said that she has already worked many nights to prove that she is equal or even better than some male colleagues. She has already worked twenty four hours without stopping, eating, or having a bath. The demand is much larger.

Male executives also related that women need to show much more than them that they are competent:

"Man, irrespective of whether or not he wants, has to work out of home. It is a rare situation when a woman manager is not competent, because she has been going through an earlier and heavier selection than men. Women must prove their competence. A woman who puts career ahead of family has to work harder". (female executive 1)

The competition to win a place in an environment phrased as "masculine" is large and consequently causes women to use more masculine characteristics to be in this place:

"The woman passes by a necessity of reaffirmation to show her ability and authority. Gentleness does not look good. We must change our original style, attitude and tone of voice to be boss. The woman cannot be too masculine, but cannot be too feminine. The feminine side of us is to stay at home". (female executive 2 )

These data support the theory studied in this paper. Other researches, also with Brazilian female executives, show that women who reach power in organizations have a style more "rational", more "lo- gical", less "emotional", as is the speech of most male executives. Either the woman fits the requirements or ends up leaving. The reports concerning the barriers to promotion posed by this predominance of the masculine were frequent, as was said by another female executive:

"Promotion in career is more difficult for women;
the fact of being a very masculine company
favors the promotion of man. The effort from
women should be higher. Our universe is sexist,
the woman must do more to stand out". (female
executive 3)

The female executives that do not possess these characteristics as the most important suffer. They managed to break the "glass ceiling" in organizations, but the weight they carry is still too great. One female executive even said that she feels like raped during several times when performing her duties because she has to react in a way which is the opposite of her nature. She is often aggressive, punches the table and swears. When has just made that scene, feels that she was raped.

It is evident that to be "among them" is necessary to set aside an attitude so-called feminine. One female executive said that as they need to invest in the career, in the end they really become more masculine.

For some male executives the feminine generation that is now arriving in the organizations (generation that was grown up with their mothers already working in the labor market) is more rational, more competitive. These women of 20 and 30 years are in a more similar logic of man than in the past.

Moreover, the prejudice is obvious in relation to the woman in organizations, even in higher positions. One female executive reported that was attending a meeting with her director and when she started to do some calculations on her hand calculator, some directors congratulated her for being very fast and efficient. They were impressed with the ability of a person who is supposed to be only a "secretary".

Another prejudice is evident in the speech of a male top manager in a huge industrial plant, place for "tough guys":

"At the time of hiring for operation, when it ties I opt for a man, because I do not know how she will adapt to the function / to the demands of the function: heat, dust, dirt, coarse guys, being 
able to arrive at midnight with the plant stopped, angry people. (female executive 2)

Many were the female executives who said there is a predisposition to listen to the man as if he spoke something more consistent. In the beginning there is much mistrust. However, after the woman reveals her competence, they trust.

Women executives face a contradiction: on the one hand, the pressure from companies for women to take an attitude "more masculine". On the other hand, the pressure of society for a "more feminine" role, that is, having a family, caring for a home and especially, having children.

A female executive presents the experienced "prejudice" when making the choice of not having children. At forty-odd years she has chosen to remain childless. She believes it is the only possible option for a woman to hold an important function, as one of an executive, with quality. She was very poorly understood by her family and by women colleagues, misunderstood, especially, because she still has time to have babies.

In addition to the data related to the profile of female executives, the research has also revealed other important factors related to gender. The first factor is relative to some values that are somehow being changed within organizations. Women who are at the top have more masculine characteristics, but many male executives advocate the necessity of their female co-workers at top positions and some of them even accept and understand the existing differences between men and women.

One male CEO presented this when was talking about a female colleague, who is a director. He said that she is one of the most efficient people he has ever worked (men and women) and that he understands when she goes to the beauty salon in the middle of the day. This male executive sees this feminine necessity as something natural. He knows that it is important for women to care about the appearance and that this reflects on the job. He agrees with the situation of this female professional living in the middle of the afternoon, since she can stay up to 10 o' clock at night if and when needed.

A young male executive with thirty-odd years, despite being the minority in this research, who reached the third level, emphasizes that he was no longer expa- triate because his wife could not go with him. Another young male executive (in a group of eight executives we usually found one who told about it) said that he could manage a way for his wife to go along with him.

Therefore, the research also showed another aspect: the discussion about what is masculine and feminine. What activities are more masculine and what activities are more feminine nowadays? Some male executives told that they saw no problem in sharing household chores.

\section{Final Considerations}

In large companies (MNCs and Brazilian) operating in Brazil we can see that women who reach top positions $(24.7 \%)$ are ESTJ. People of this psychological type are naturally a leader and take the command quickly. It is noteworthy that in this type there is no presence of preference $(\mathrm{F})$ that tells about the feeling. Therefore, we can assess that among the Brazilian female executives who reach the top of an organization the characteristic which prevails in their behavior is not related to the aspects of greatest interest in people. People who are in strategic positions prefer more objective, rational and planned behaviors.

The presence of type ESTJ also striking among Brazilian female executives can be explained by the fact that the organizational environment still presents a rather masculine culture. As noted in the theoretical framework of this paper, there is a discourse about the incorporation of feminine values in business, however it has not materialized yet. Therefore, the women who want to arrive and stay at the top need to adopt a male model of performance. Furthermore, using some observations of Belle (1994), we cannot forget that women come in structured organizations, in principle, in a masculine way of idealization and in the absence of female models they identify themselves primarily with male models. And, possibly, they are only accepted if they proceed this way.

Other data that support this analysis is in relation to the dismembered MBTI. The biggest difference occurred between $(\mathrm{F})$ that stands for feeling and $(\mathrm{T})$, thought. The highest percentage $(82.6 \%)$ was to the preference related to the thought. These are people who have strong abilities to act in executive areas, value logic 
more than feeling, that is, more "male" than "female". They are more interested in things than in human relations. This factor was observed among both men and women who reached the power of hierarchy in Brazil.

The data suggest that business environment in Brazil, which is strongly masculine, may have succeeded in implementing a powerful filter to allow only those women which have almost the same psychological type as their fellow men to climb the ladder in order to reach beyond the glass ceiling.

In large companies operating in Brazil we can see that women who reach high positions face multiple barriers in their daily work. The first presented point was regarding the need to show more competence at work. Both men and women agree that the female executive needs to show much more work than the male executive.

As noted in the theoretical framework of this paper, there is a discourse on the incorporation of feminine values in business, however it has not materialized yet. Reports show that some values are being modified, as for example, the fact that some male executives "see" and accept the existing differences between men and women. However, what happens most is still the opposite: women are identifying themselves with the male models of performance and possibly only being accepted if they behave like this. Despite the discourse of equality, changes are small when analyzing the hierarchical division of labor.

However, even facing all these difficulties and prejudices, the female executives who reached beyond the glass ceiling in Brazil are proud to have made it and do not want to go back home.

\section{Agradecimentos}

- ao CNPq, pela bolsa de produtividade que vem apoiando esta pesquisa.

- à CAPES, pelo apoio concedido via PROSUP para a pesquisa nesta temática.

- à FAPEMIG - Fundação de Amparo à Pesquisa do Estado de Minas Gerais - pelo apoio concedido à pesquisa que subsidiou este artigo.

\section{REFERENCES}

\section{ABRAMO, L. W. A inserção da mulher no mercado}

de trabalho: uma força de trabalho secundária?

Doctoral Thesis. Faculdade de Filosofia, Letras e Ciências Humanas. Programa de doutorado em sociologia. Universidade de São Paulo, São Paulo, 2007.

AGUIAR, G. S. Diversidade no Trabalho: os desafios em ser mulher em uma organização financeira. Master's Thesis. Faculdade de Economia, Administração, Contabilidade e Ciência da Informação e Documentação. Programa de Pós-graduação em Administração. Universidade de Brasília, Brasília, DF, 2007.

BELLE, Françoise. Executivas: quais as diferenças na diferença? In: CHANLAT, J. F. O Indivíduo na organização: dimensões esquecidas. São Paulo: Atlas, 2001.

BOAS, L. H. B. V.; NETO, A. P.; CRAMER, L. Relações de gênero nas organizações: um estudo no setor de vendas de veículos. Revista de Administração da Universidade de São Paulo, São Paulo, v. 38, n. 3, p. 219-229, 2003.

BOSCARIN, R.; GRZYBOVSKI, D.; MIGOTT, A. M. B. Mulher, conhecimento e gestão empresarial: um estudo nas empresas familiares. In: ENANPAD 2001 - ENCONTRO NACIONAL DOS PROGRAMAS DE PÓS-GRADUAÇÃO EM ADMINISTRAÇÃO, Campinas. Anais... Curitiba: ANPAD, 2001. CD-ROM.

BOTELHO, L. L. R.; MORAES, L. V. S.; CUNHA, C. J. C. A. Ascensão profissional feminina: um caminho bem mais tortuoso do que se imagina. Fazendo Gênero: Corpo,

Violência e Poder, Florianópolis, v. 8. 2008.

BRUSCHINI, C.; PUPPIN, A. B. Trabalho de mulheres executivas no Brasil no final do século XX. Cadernos de Pesquisa, Rio de Janeiro, v. 34, n. 121, p. 105-138, 2004.

CAPPELLE, M. C. A. et al. Uma análise da dinâmica do poder e das relações de gênero no espaço organizacional. RAE eletrônica, [on-line], v. 3, n. 2, 2004. 
CRESWELL, John W. Research Design: qualitative, quantitative and mixed method approaches. London: Sage, 2003.

EVANS, G. Nos negócios, jogue como homem, vença como mulher. São Paulo: Futura, 2000.

FRIEDAN, B. Mística feminina. Petrópolis, RJ: Vozes Limitada, 1971.

HOFSTEDE, Geert. Culturas e organizações: compreendendo a nossa programação mental. Silabo: Lisboa, 1991.

JACKSON, J. C. Women middle management perception of the glass ceiling. Woman in management review, Bingley, UK, v. 16, p. 30-45, 2001.

LEITE, C. L. P. Mulheres: muito além do teto de vidro. São Paulo: Atlas, 1994.

LIMA, G. S. Os desafios da carreira da mulher executiva no Brasil. Master's Thesis, Programa de Pós-graduação em Administração. Pontifícia Universidade Católica de Minas Gerais, Belo Horizonte, 2009.

MAGESTE, G. S.; MELO, M. C. O. L.; CKAGNAZAROFF, I. B. Empoderamento de mulheres: uma proposta de análise para as organizações. In: ENEO 2008 ENCONTRO DE ESTUDOS ORGANIZACIONAIS DA ANPAD, Belo Horizonte. Anais... Belo Horizonte: V Encontro de Estudos Organizacionais da ANPAD 2008. CD-ROM.

MATTAR, F. N. Pesquisa de marketing: metodologia, planejamento. 5. ed. São Paulo: Atlas, 1999.

MIRANDA, L. C. A percepção da mulher no mercado de trabalho: emprego, carreira ou vocação. Master's Thesis. Faculdade de Economia e Finanças IBMEC.

Programa de Pós-graduação e pesquisa em Administração e Economia, Rio de Janeiro, 2006.

MORGAN, G. Imagens da organização. São Paulo: Atlas, 1996.

MYERS, I. B. Gifts differing. Palo Alto, CA: Consulting Psychologists Press, Inc., 1980.
MYERS, I. B. 1995. Introdução à Teoria dos Tipos

Psicológicos: um guia para entender os resultados do myers-briggs type indicator. Palo Alto, CA: Consulting Psychologists Press, Inc., 1995.

MYERS, I. B.; MCCAULLEY, M. H. Manual: a guide to the development and use of the Myers-Briggs Type Indicator. Palo Alto, CA: Consulting Psychologists Press, Inc., 1985.

MYERS, I. B.; MYERS, P. B. Ser humano é ser diferente: valorizando as pessoas por seus dons especiais. São Paulo: Gente, 1997.

OLIVEIRA, P. M.; MURITIBA, S. N.; CASADO, T.

Diferenças individuais dos estudantes e preferência por métodos de ensino em Administração: Uma aplicação dos tipos psicológicos de Jung. In: XXVIII ENANPAD 2004 - ENCONTRO NACIONAL DOS PROGRAMAS DE PÓSGRADUAÇÃO EM ADMINISTRAÇÃO, Curitiba. Anais... Curitiba: XXVIII Encontro da ANPAD 2004. CD-ROM.

PERROT, M. Mulheres públicas. Translation Roberto Leal Ferreira. São Paulo: Fundação Editora da UNESP, 1998.

PORTO, M. F. S. Pérolas em chão árido: organização, ação social, ação política e cultura política de mulheres empresárias no estado de Minas Gerais. Master's Thesis. Universidade Federal de Minas Gerais. Programa de Pósgraduação em História e Culturas Políticas, 2007.

RAGO, M. Trabalho feminino e sexualidade. In: PRIORE, M. D. História das mulheres no Brasil. 5. ed. São Paulo: Contexto, 2001.

REVISTA Exame Melhores e Maiores. As 500 maiores empresas do Brasil. July, 2005.

ROCHA-COUTINHO, M. L. Quando o executivo é uma "dama": A mulher, a carreira e as relações familiares. In: FÉRES-CARNEIRO, T. Família e casal: arranjos e demandas contemporâneas. Rio de Janeiro: PUC Rio, São Paulo: Loyola, 2003.

STEIL, A.V. Organizações, gênero e posição hierárquica: compreendendo o fenômeno do teto de vidro. Revista de Administração, São Paulo, v. 32, n. 3, p. 62-69, 1997. 
TANURE, B.; CARVALHO NETO, A.; ANDRADE, J. O.

A Super Executiva às voltas com carreira, relógio biológico, maternidade, amores e preconceitos. In: ENANPAD 2006 - ENCONTRO NACIONAL DOS PROGRAMAS DE PÓS-GRADUAÇÃO EM ADMINISTRAÇÃO, Salvador. Anais... Salvador: ANPAD, 2006. CD-ROM.

TANURE, B.; CARVALHO NETO, A.; ANDRADE, J.

Executivos: sucesso e (in)felicidade. Rio de Janeiro:

Elsevier, 2007.

THIRY-CHERQUES, H. R.; PIMENTA, R. C. Condição feminina e percepção dos valores morais no nível técnico e gerencial das organizações brasileiras. In: ENANPAD 2003 - ENCONTRO NACIONAL DOS PROGRAMAS DE PÓS-GRADUAÇÃO EM ADMINISTRAÇÃO, Atibaia.

Anais... Atibaia: ANPAD 2003. CD-ROM. 